\title{
Assessment of knowledge, attitudes and practices about sun exposure and sunscreen usage in outpatients attending a Dermatology Clinic in North India
}

\section{Mrinal Gupta}

\author{
Department of Dermatology, Treatwell Skin Centre, Jammu and Kashmir, India
}

Corresponding author: Dr. Mrinal Gupta, E-mail: drmrinalgupta@yahoo.com

\begin{abstract}
Background: There has been a significant increase in the cases of skin cancer throughout the world in the last few decades. Sun exposure and photoprotection-related behavior and knowledge are important aspects in the prevention of skin cancer. Despite various recommendations advising individuals to reduce their sunexposure, many people still do not utilize these sunprotection strategies. Aims and Objectives: To assess the knowledge, attitude and practices about sun exposure and sunscreen usage in outpatients attending a dermatology clinic Materials and Methods: Three hundred consecutive patients attending a dermatology clinic were enrolled for this questionnaire-based cross-sectional, descriptive study. Results: A total of 300 patients, comprising of 112 (37.33\%) men and 188 (62.67\%) women, aged between 14 and 78 (mean 47.13) years, were included in the study. Majority of the patients, 216 (72\%) were in the 20-60 year age group and 226 (75.33\%) belonged to an urban background. Assessment of the sunexposure revealed that 224 (74.67) respondents reported daily sunexposure whereas 76 (25.33\%) had occasional sunexposure. Assessment of the knowledge revealed that $241(80.33 \%)$ patients were aware of the adverse effects of excessive sunexposure but only 139 (46.33\%) were aware of the carcinogenic effect of sunlight. A total of 212 (70.67\%) respondents were aware of the benefits of sunscreens but only 156 (73.58\%) were using the sunscreens. Sixty one respondents (39.1\%) reported that they used sunscreens on a daily basis while 95 (60.89\%) used it occasionally. Lack of awareness was the most common reason (44.67\%). Newspapers (47\%) and television (39\%) were the most common source of information in our respondents. Conclusions: Information, education, and communication activities are imperative to educate people regarding the risks of excessive sunexposure and significance of preventive measures like sunscreens to bridge the gaps in their knowledge. While improvement in individual economic status and education remains highly desirable, mass media can play a pivotal role in creating awareness among masses.
\end{abstract}

Key words : Skin cancer, UV radiation, Sunscreeen, Photoprotection

\section{INTRODUCTION}

The sun is the principal source of environmental ultraviolet radiation (UVR). Excessive UVR exposure to skin leads to widespread epidermal and dermal cellular damage. DNA is probably the primary molecular target of injury, as a result of both direct UVB absorption and also secondary UVA-induced photosensitization reactions. The acute harmful effects of ultraviolet rays on the skin include damage to DNA, apoptosis, erythema, immunosuppression and an increase in pigmentation due to stimulation of melanogenesis, while the long-term effects include photoaging and photocarcinogenesis. Epidemiological studies have reported an increasing prevalence of cutaneous malignancies, which has been attributed to factors like large quantities of UV radiation entering the atmosphere due to the thinning of the ozone layer,

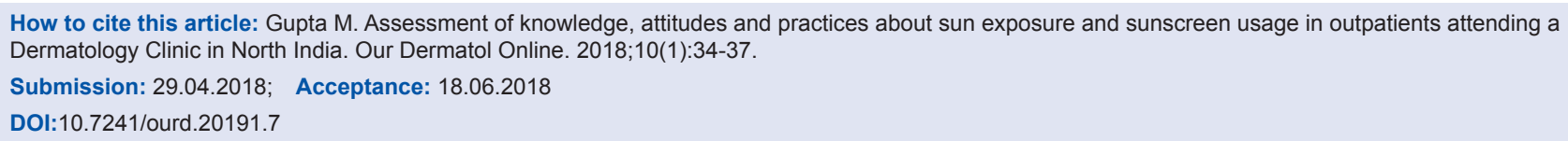


living and travelling in sunny climates, excessive sunbathing and sun bed use, outdoor sports, and the usage of appliances and devices that emit UV radiation in domestic and industrial settings [1].

Sun exposure and photoprotection-related behavior and knowledge are important aspects in the prevention of skin cancer and photodermatoses. Primary skin cancer prevention strategies include increasing knowledge and awareness in individuals, changing sun protection behavior and implementing environmental policies and interventions. It is estimated that the regular use of photo-protectors during childhood may reduce the incidence of skin cancer by almost $80 \%$ [2]. The various protective strategies advocated include appropriate use of sunscreens, avoidance of UV exposure by seeking shade, staying indoors during the hours of peak UV radiation, and wearing protective clothing. Unfortunately, patient adherence to these recommendations has been disappointingly low and various barriers have been identified which include lack of knowledge, misconceptions regarding skin cancer risks, difficulty in initiating behavioral changes, and socioeconomic factors such as time and costs involved, etc [3].

This study was carried out to assess the knowledge, attitude and practices about sunexposure and sunscreen usage in outpatients attending a dermatology clinic.

\section{MATERIALS AND METHODS}

Consecutive patients attending outpatient dermatology clinic during July 2015 to June 2016 were enrolled for this questionnaire-based, cross-sectional, descriptive study. Children aged $<14$ years and severely ill patients were excluded from the study owing to their inability to comprehend or respond to the questionnaire. After informed written consent and assuring confidentiality, they were asked to answer a predesigned, structured questionnaire in their native language. The questionnaire had two parts with the first section for their sociodemographic details and the second section comprised questions aimed at assessing their knowledge, attitude, and perception for sunexposure and photoprotection.

\section{RESULTS}

A total of 300 patients, comprising of $112(37.33 \%)$ men and 188 (62.67\%) women, aged between 14 and
78 (mean 47.13) years, were included in the study. Their baseline demographic features are shown in Table 1. Majority of the patients, $216(72 \%)$ were in the 20-60 year age group and $226(75.33 \%)$ belonged to an urban background. Among the males, self employed and office workers were the most common occupational group ( $10.67 \%$ and $11.33 \%$ respectively), while among the females, homemakers were the most common group (48\%). Fitzpatrick skin type III $(27.33 \%)$ and IV (47.33\%) were the most common skin types in our study. Assessment of the sunexposure

Table 1: Baseline characteristics of patients studied

\begin{tabular}{|c|c|}
\hline Baseline characteristics & $\begin{array}{l}\text { Number of patients (\%) } \\
\qquad n=300\end{array}$ \\
\hline Gender & $112(37.33)$ \\
\hline Males & $188(62.67)$ \\
\hline Females & $1: 1.69$ \\
\hline Male: female & 28 (9.33) \\
\hline \multicolumn{2}{|l|}{ Age (years) } \\
\hline$<20$ & $28(9.33)$ \\
\hline $20-40$ & $102(34)$ \\
\hline $41-60$ & $114(38)$ \\
\hline$>60$ & $56(18.67)$ \\
\hline \multicolumn{2}{|l|}{ Social Background } \\
\hline Rural & 74 (24.67) \\
\hline Urban & 226 (75.33) \\
\hline \multicolumn{2}{|l|}{ Occupation } \\
\hline \multicolumn{2}{|l|}{ Men } \\
\hline Office Workers & $32(10.67)$ \\
\hline Self-Employed & 34 (11.33) \\
\hline Students & $26(8.67)$ \\
\hline Farmers and Laborers & $16(5.33)$ \\
\hline Defense Person & $4(1.33)$ \\
\hline \multicolumn{2}{|l|}{ Women } \\
\hline Homemakers & $144(48)$ \\
\hline Students & $30(10)$ \\
\hline Office Workers & $14(4.67)$ \\
\hline \multicolumn{2}{|l|}{ Education Status } \\
\hline $\begin{array}{l}\text { Illiterate/School dropout } /<12^{\text {th }} \\
\text { standard }\end{array}$ & $56(18.67)$ \\
\hline Graduate & $156(52)$ \\
\hline Postgraduate & $78(26)$ \\
\hline Professional & $10(3.33)$ \\
\hline \multicolumn{2}{|l|}{ Fitzpatrick Skin Type } \\
\hline Type II & $12(4)$ \\
\hline Type III & $82(27.33)$ \\
\hline Type IV & $142(47.33)$ \\
\hline Type V & $60(20)$ \\
\hline Type VI & $4(1.33)$ \\
\hline \multicolumn{2}{|l|}{ Source of information } \\
\hline Television & $117(39)$ \\
\hline Radio & $36(12)$ \\
\hline Newspaper & $141(47)$ \\
\hline Books & $81(27)$ \\
\hline Internet & 59 (19.67) \\
\hline Health personnel & $31(10.33)$ \\
\hline Family and friends & $42(14)$ \\
\hline No information & 38 (12.67) \\
\hline
\end{tabular}


revealed that 224 (74.67) respondents reported daily sunexposure whereas $76(25.33 \%)$ had occasional sunexposure. Among the respondents who had daily sunexposure, 102 (45.53\%) had less than one hour of sunexposure daily whereas $96(42.86 \%)$ had an exposure of 1-3 hours per day and only $26(11.6 \%)$ had sunexposure more than three hours daily.

Assessment of the knowledge revealed that 241 (80.33\%) patients were aware of the adverse effects of excessive sunexposure but only 139 (46.33\%) were aware of the carcinogenic effect of sunlight. The most frequently identified adverse effects were sunburn (60.33\%), blemishes (49\%), freckles (42.3\%), aging (31.33\%) and wrinkles (29.66\%), skin cancer (46.33\%) and aggravation of acne $(19.33 \%)$. When questioned regarding the awareness about sunscreens, $212(70.67 \%)$ respondents were aware of the benefits of sunscreens and females $(n=140)$ were more aware than the males $(n=72)$, but only 156 (52\%) were using the sunscreens. Of the 156 users of sunscreens, females $(n=102)$ outnumbered the males $(n=54)$. Sixty one respondents $(39.1 \%)$ reported that they used sunscreens on a daily basis while 95 (60.89\%) used it occasionally. When asked about the sunscreens, 74 (47.43\%) users were aware of the Sun Protection Factor (SPF) of the product they were using and $64(41.02 \%)$ respondents were using a sunscreen with $\mathrm{SPF} \geq 30$. Among the users of sunscreens, only $32(20.51 \%)$ were using them twice a day and only 39 (25\%) were using it over all the exposed sites including face, neck, arms and hands while the rest reported applying it over the face and neck only. The amount of sunscreen used per application was significantly less and $76.28 \%$ of the users $(n=119)$ were applying less than $5 \mathrm{ml}$ sunscreen over the face and neck per usage. When enquired about the reasons for not using sunscreens, lack of awareness was the most common reason $(44.67 \%)$, followed by whitish discoloration and excessive oiliness of the face postusage $(21.33 \%)$, lack of time for application (10.66\%) and cost of sunscreens (5.33\%). Newspapers (47\%) and television (39\%) were the most common source of information in our respondents, followed by books and internet but 38 (12.67\%) respondents had no idea about the sunscreens.

\section{DISCUSSION}

Ultraviolet (UV) radiation has been classified by the International Agency for Research on Cancer (IARC) as a Group 1 carcinogen to humans [4]. Sun protection is therefore an important public health message for skin cancer prevention. Experts advocate the use of sunscreen, as well as other sunprotective measures like wearing protective clothing and sunglasses, wearing widebrimmed hats, and sun-avoidance to protect from sun exposure. Sunscreens have been proven to have protective effects against photoaging and reduce the incidence of skin cancers [5].

This population-based survey documents that the knowledge about risks of solar radiation in general population is suboptimal and even in respondents with adequate knowledge, the sunscreen usage is inadequate. In the present sample, $80.33 \%$ patients $(n=241)$ were aware of the adverse effects of excessive sunexposure but only $46.33 \%(n=139)$ were aware of the relationship between sunexposure and skin cancers, which is much lower than those of the western populations. In a Brazilian study, $94.3 \%$ of the respondents were aware of the risks of sun exposure and $80.8 \%$ knew that the sunlight increases the risk of skin cancer [6]. In a study performed at the National Institute of Cancer on the USA, it was found that $77 \%$ of the participants knew that the sun increases the risks of skin cancer [7]. This low level of awareness in our study population could be attributed to minimal public awareness campaigns in our setup.

The knowledge regarding the sunscreens and their usage was higher among the females in our study, which was similar to the results of other studies. Devos et al. showed that knowledge regarding sunscreens and their regular use was considerably higher in the female participant group than in the male group [8]. Yurtseven et al also showed that while $90.6 \%$ of women used sunscreen, only $57.1 \%$ of men were using sunscreens [9]. In our study also, of the 156 users of sunscreens, females $(n=102)$ outnumbered the males $(n=54)$. This can be related to the fact that women are more concerned about cosmetics and skin care. In our study $52 \%$ respondents were using sunscreens, out of which only $20.33 \%(n=61)$ were using sunscreens on a regular basis. In a study by Fabris et al [6], 74.1\% respondents were using sunscreens on a regular basis, whereas in a study by Al-Mutairi et al. [10], $80 \%$ of the respondents had been using sunscreens regularly and $27 \%$ were using repeated applications of sunscreen. In our study, $47.43 \%(n=74)$ users were aware of the SPF of the product they were using, while $96 \%$ of sunscreen users were aware of the product's SPF in the study by Al-Mutairi [10]. The amount of sunscreen is an important factor in determining the sunprotection 
offered by the product. A European study showed that individuals used one-fifth $(0.3-0.5 \mathrm{mg} / \mathrm{cm} 2)$ of the quantity recommended by the manufacturer on the product packaging $\left(2 \mathrm{mg} / \mathrm{cm}^{2}\right)$ [11]. In our study too, only $23.72 \%(n=37)$ users were using an adequate amount of sunscreen. Lack of awareness was the most common reason cited by the respondents for not using sunscreens in our study, while in a Brazilian study, the lack of patience to apply (34.2\%), followed by messing up the $\tan (31.6 \%)$ were the most common reasons [6]. Television and the printed media were the most common sources of information in our study, more so than health professionals.

Experience from various countries demonstrates that it is possible to improve the sun protection behaviors and attitudes of a population with public health campaigns. Use of television and the printed media, particularly newspapers, are the key in targeting a large population but campaigns should also incorporate alternative approaches such as healthcare professionals and the internet to make these campaigns more effective.

\section{CONCLUSIONS}

As the incidence of skin cancers is on the rise, proper education of the masses regarding the adverse effects of sunexposure and the use of various photoprotective measures including sunscreens is imperative. The respondents evaluated in our study had an acceptable understanding of the risks of sun exposure; however, large majority were unaware of benefits of sunscreens or were not using sunscreens in a proper manner to be of any benefit.

\section{LIMITATIONS}

There were several potential limitations in our study. Firstly, the sample size was small and as convenience sample of respondents from only one centre was surveyed; thus, caution must be exercised in extending our findings to the whole population, especially in other geographical regions. Moreover, results of this study rely on self-reported data, which could introduce recall and social desirability biases.

\section{Statement of Human and Animal Rights}

All procedures followed were in accordance with the ethical standards of the responsible committee on human experimentation (institutional and national) and with the Helsinki Declaration of 1975, as revised in 2008.

\section{Statement of Informed Consent}

Informed consent was obtained from all patients for being included in the study.

\section{REFERENCES}

1. Diepgne TL, Mahler V. The epidemiology of skin cancer. Br J Dermatol 2002;146(Suppl 61):1-6.

2. Balato N, Gaudiello F, Balato A, Monfrecola G. Sun habits in the children of southern Italy. J Am Acad Dermatol. 2007;57:883-7.

3. Melia J, Pendry L, Eiser JR. Harland C, Moss S. Evaluation of primary prevention initiatives for skin cancer: a review from a U.K. perspective. Br J Dermatol. 2000;143:701-8.

4. The International Agency for Research on Cancer Working Group on artificial ultraviolet (UV) light and skin cancer. Int J Cancer. 2006; 120:1116-22.

5. Geller A, Cantor M, Miller D, Kenausis K, Rosseel D, Rutsch L, et al. The Environmental Protection Agency National Sun Wise School Program: Sun protection education in US schools (19992000). J Am Acad Dermatol. 2002;46:683-9.

6. Fabris MR, Martignago BC, Fabris TR, Duraes ES, Blanco LF. Assessment of knowledge of skin cancer prevention and its relation with sun exposure and photo protection amongst gym academy members on the south of Santa Catarina, Brazil. An Bras Dermatol. 2012;87:36-43.

7. Gebert B, Johnston K, Bleecker T, McPhee S. Attitudes about skin cancer prevention: A qualitative study. J Cancer Educ. 1996;11:96-101.

8. Devos SA, Baeyens K, Van Hecke L. Sunscreen use and skin protection behavior on the Belgian beach. Int J Dermatol. 2003;42:3526.

9. Yurtseven E, Ulus T, Vehid S, Koksal S, Bosat M, Akkoyun K. Assessment of Knowledge, Behaviour and Sun Protection Practices among Health Services Vocational School Students. Int J Environ Res Public Health. 2012;9:2378-85.

10. Al-Mutairi N, Issa BI, Nair V. Photoprotection and vitamin D status: A study on awareness, knowledge and attitude towards sun protection in general population from Kuwait, and its relation with vitamin D levels. Indian J Dermatol Venereol Leprol. 2012;78:342-9.

11. Autier P, Boniol M, Severi G, Dore JF. Quantity of sunscreen used by European students. Br J Dermatol. 2001;144:288-91.

Copyright by Mrinal Gupta. This is an open-access article distributed under the terms of the Creative Commons Attribution License, which permits unrestricted use, distribution, and reproduction in any medium, provided the original author and source are credited.

Source of Support: Nil, Conflict of Interest: None declared. 